\title{
THE QUESTION OF THE DANUBE AND THE PLANNING MYOPIA
}

\author{
Sârbu Cătălin N., ${ }^{1}$ Mitrea Andrei, ${ }^{2}$ Chiș Alin D. ${ }^{3}$ \\ ${ }^{1}$ School of Urban Planning, ,Ion Mincu' University of Architecture and Urban \\ Planning, Bucharest (ROMANIA) \\ ${ }^{2}$ School of Urban Planning, ,Ion Mincu' University of Architecture and Urban \\ Planning, Bucharest (ROMANIA) \\ ${ }^{3}$ School of Geography, University of Bucharest, Bucharest (ROMANIA) \\ sarbu52 [at] yahoo.com, andrei.mitrea [at] uauim.ro, alin.d.chis [at] \\ gmail.com
}

\begin{abstract}
This is our first paper in a sequence of studies dedicated to the Danube. Hence, the following text should be considered as an introduction to a more ambitious research project in the field of spatial planning. In essence, the article forms a critical synthesis of the various arguments that have been put forward over the past hundred years in support of the Danube's significance as a vector for development. This exercise in synthesis is both a necessary and an instructing prerequisite for the entire research project: In due course, we wish to formulate a basic set of hypotheses concerning Romania's development in connection to the Danube. If proven feasible, we wish to subsequently test them in as much detail as possible.
\end{abstract}

The rationale behind this review paper is a reasoned examination of the functions the Danube can still fulfil from a Romanian spatial planning perspective.

Keywords: Danube, Romanian Studies of the Danube, Romanian Planning Myopia

\section{INTRODUCTION}

This is a position paper. It forms the starting point of a larger research project we have been contemplating for some time now. While gradually delving deeper into its subject matter, we became increasingly interested in the following research question: What is the precise role the Danube can play in Romania's spatial development? Upon closer inspection, we became aware that the level of detail with which one wishes to answer this question is extremely important.

We shall be examining this question from a spatial planning perspective. Apart from a purely scientific interest in the matter, our motivation is also associated with the current state of affairs in Romanian spatial planning, which we find increasingly vexing. Thus, when it comes to the Danube, there is a plethora of personal opinions and pseudo-scientific arguments permeating public and professional discourses. The project for the Bucharest - Danube Canal is an excellent case in point. To a lesser degree, the same applies to the Danube - Black Sea Canal. Both projects are usually perceived as megalomaniac, by planning 
professionals and laymen alike, with little consideration given to their rationale from a planning perspective. Furthermore, we have encountered very often a severe case of myopia in contemplating international affairs when discussing the Danube and spatial development.

Fortunately, this state of affairs is at least partly explained by a lack of focalised literature. There are virtually no recent works of synthesis dealing with the Danube. A similar lack of historical planning perspective pervades political statements, such as the European Union's Strategy for the Danube Region, which are of little use, except for pursuing programming goals [1], [2]. It is therefore impossible to give a straightforward answer to our research question. Hence, the pressing need for this research exercise.

\section{METHODOLOGY}

\subsection{Research Strategy}

Essentially, the research strategy behind the project is straightforward: to critically assess domestic and international research conducted upon the Danube from a spatial planning perspective, and to test the arguments put forward in support for the Danube's significance for Romanian development.

However, for the purpose of this paper, we have confined ourselves to producing an adequate study of the dominant themes within the dedicated literature. Such an exercise proved valuable in two respects: it produced a much needed state of the art, both at a national and an international research level, while at the same uncovering future avenues for enquiry. Thus, each section ends with at least one future research direction, which has been poorly covered to date.

Nonetheless, putting this strategy into practice proved exceedingly difficult. Unfortunately, reasons are not very hard to find: Firstly, there is a great shortage in information when studying the Danube from a spatial planning perspective. This scarcity involves a rather irksome lack of dedicated Romanian literature, as well as missing or incomplete spatial datasets. And secondly, we were unable to find a single work of synthesis that comprises an historical overview of the various arguments linking the Danube to Romania's development. We shall return to each of these matters within the following sections.

\subsection{Data Quality and Collection}

Since there is no readily available synthesis, we had to construct one of our own, based on an extensive literature review. However, gaining access to the necessary materials was no mean feat. We relied on three main sources: the first source consisted of the texts available from the Central University Library in Bucharest; the second source comprised our privately owned texts, which, quite surprisingly, do not always appear in the library's repository, and finally, a third source was the collection of digitised texts, provided by the Metropolitan Library of Bucharest.

While we could easily gain access to the digital copies provided by the Metropolitan Library, and subsequently complement them with our own books and articles, materials from the Central University Library are difficult to obtain, as there are no 
digital copies readily available, and the process of requesting materials is both cumbersome and somewhat outmoded.

Nonetheless, we were fortunate enough to gain access to Rudescu and Banu's ,Bibliographie roumaine du Danube Inferieur' [3]. Published in 1969, it is the most comprehensive bibliographical work to date, and therefore providing for an excellent benchmarking tool. As we had expected, we were not able to track down all the relevant titles appearing within the work. It is therefore necessary to continue our bibliographical quest in other libraries, in the hope of unearthing new references.

\subsection{Data Processing}

There is little raw data processing behind this paper, as most of it relies on a critical literature review. We have therefore relied on secondary sources whenever we have deemed it necessary to illustrate the text with figures. Verifying their accuracy was less important at this stage, as they were only used for illustration purposes. This approach will change drastically as we progress to the subsequent stages of this research project.

\section{RESULTS}

In order to produce a clearer overview of our progress thus far, we have chosen to divide this section into two parts. Hence, the following subsection chronicles the dominant themes appearing within the Romanian literature over the past century. It serves as reference framework for the following subsection, which discusses the benefits and deprivations of the Danube from an international perspective. In addition, this latter part explains the major functions of the Danube from an historical perspective. Whenever practicable, we have highlighted novel and promising research directions.

\subsection{Dominant Themes within Romanian Studies Dedicated to the Danube}

As mentioned earlier, there used to be a rich body of Romanian literature dedicated to the Danube [3]. However, this research tradition became virtually extinct by the late 1970s. Regrettably, we were unable to find any documented reasons for this inexplicable loss of interest in matters related to the Danube. We might speculate, however, that such an abrupt halt in research endeavours might point towards some noticeable degree of political and ideological involvement.

We therefore suspect that sensitive research exercises, such as studies in the law and politics of the Danube, were gravely frustrated by the effects of the 1971 'July Theses' and the ensuing tautness of the academic environment [4]. Nevertheless, the exact constellation of these impacts still eludes us, as they have been poorly documented to date. Note however, that Romanian research traditions have been subjected repeatedly to cycles of alternating political pressures [5]. Hence, a rigorous explanation can only be historical in character.

Set against this background, the following table is a summary of the dominant themes within the Romanian literature dedicated to the Danube (cf. Table 1). 


\section{\#1/2016 CHALLENGES FOR THE NEW MILLENNIUM}

\begin{tabular}{|c|c|}
\hline Period & Dominant Themes \\
\hline Pre-war & $\begin{array}{l}\text { After the conclusion of the Independence War of } 1877-1878 \text {, the Kingdom of } \\
\text { Romania comes into possession of Dobruja, thereby gaining direct access to } \\
\text { the Black Sea. Within this novel political context, authors of this period tend to } \\
\text { focus on the following themes: } \\
\text { - The rising importance of Constanta as a port. Areas of scientific and } \\
\text { technical interest include its overhaul in the face of rapidly increasing } \\
\text { exports, as well as its connection to Bucharest [12]; } \\
\text { - A period of synthesis in hydrobiological research, seen from an } \\
\text { economic perspective [9]; } \\
\text { - Beginning of the land reclamation debate between Antipa and Saligny } \\
\text { [6], [7], [8], [10], [15]. An important topic in this debate were coastal } \\
\text { and river defences [14]; } \\
\text { - First economic and political histories of the Danube [11], [13], [16]. }\end{array}$ \\
\hline Interwar & $\begin{array}{l}\text { After the conclusion of the First World War, Romania becomes engaged in } \\
\text { renegotiating her diplomatic position at the mouths of the Danube in relation } \\
\text { to the European Danube Commission. } \\
\text { - The port of Constanta within international trade [18], [19], [22], [23]; } \\
\text { - A new research direction emerges: the Constanța - Cernavodă Canal } \\
\text { [20], [24], [25], [26]; } \\
\text { - Height of the land reclamation debate [17]; } \\
\text { - Efforts in establishing the navigation regime on the Danube [21]. }\end{array}$ \\
\hline
\end{tabular}

\section{Comments} output of scientific analyses and by some very healthy academic debates.

Antipa's writings essentially dominate the first decade of the $20^{\text {th }}$ century. Around 1910 however, Saligny begins challenging his views on river improvement, thus triggering the debate on land reclamation.

In addition, a first wave of historical, political and economic syntheses of the Danube emerges, amongst which Băicoianu's work is the most exquisite.

In parallel, other authors focus their attention upon the new role of Constanta, as Romania's primary outlet for agricultural produces. It is within this context that the Analele Dobrogene periodical starts publishing consistently on these matters.

The Analele Dobrogei continues to publish relevant articles on the Danube.

The land reclamation debate reaches its height. The central question was the extent of land reclamation and the design and construction of the river defences.

By now, the time of great histories of the Danube seems to have passed. 
Second World War
Between 1940 and 1944, river traffic increases on the Danube, as a result of the Romanian - German wartime co-operation. Hence, the dominant topics become:

- The statute of the Danube [27], [29], [30], [31], [33];

- Avenues for co-operation between the merchant river fleets on the Danube [28], [32].

With the establishment of the new Danube Commission in 1948, studies in international law and politics of the Danube gain momentum. Authors usually dedicate a consistent part of their enquiries to the history of diplomatic relations:

- Law and politics of the Danube, generally in connection with the problem of the Turkish Straits [34], [35], [36], [37];

- The first systematic bibliography on the Danube appears in 1969 [3]. Unfortunately, it has remained the only such work thus far;

- Systematic typological studies in settlement geography begin to appear [40], [41], [38], [39];

- Some studies dedicated to Romanian port cities on the Danube begin to appear [45]. In addition, new writings touch upon historical commercial issues of the Danube [42], [43], [44]
The Affaires Danubiennes periodical starts publishing articles about the strategic and political importance of the Danube. Writings from this period are marked by geopolitical concerns.

Romanian studies of the early 1970s generally avoid analysing and commenting upon economic diplomatic and political developments after the Belgrade Conference.

After the mid 1970 s, a hiatus sets in. Almost no relevant works focusing upon the Danube appear during the 1980 s and the 1990 s.

The 2000s and 2010s witness a modest revival in the academic interest for the Danube. However, none of the previous traditions receives serious treatment or development.

\section{Table 1: Dominant Themes in the Romanian Literature Dedicated to the Danube}


The short synopsis sketched above shows an interesting, but largely inconsistent picture. From a planning perspective, Romanian academic interest in the Danube seems to be fluctuating. Even though it is still somewhat early to make any definitive assertions, we are inclined to mark the late pre-war and early interwar periods as displaying the greatest effervescence and coherence in researching and debating matters related to the Danube. It is within this period that authors such as Antipa, Băicoianu and Vidrașcu tend to integrate historical, economic and political insights into works of a larger breadth. It might be also interesting to note that these same authors return to this subject matter repeatedly, thereby constantly refining their arguments. This historical perspective opens up new fields of enquiry in evolutionary and comparative studies.

There is also a second period of scientific expansion, which seems to start some time in the late 1960s and early 1970s, decisively supported by Rudescu and Banu's ,Bibliographie roumaine du Danube Inferieur' of 1969. Unfortunately, this renewed academic effervescence is cut short by the mid 1970s. Nevertheless, authors such as Cârțână and Seftiuc, produce some fine diplomatic histories of the Danube, albeit refraining from discussing developments after the Belgrade Conference in 1948.

Concomitantly, some less ambitious works appear during this time, generally concerned with the geography of settlements. One notable exception is Niculescu's work ,Geografia văii Dunării românești' ${ }^{1{ }^{1}}$ of 1969 . Nonetheless, this period is not completely devoid of interest, as geographers produce some interesting typological compilations in urban functions, which can encourage further studies in spatial planning.

The mid 1970s hiatus is only interrupted after the fall of the communist regime, albeit rather modestly. Thus, Bărbănțan's and Baltălungă's work seem to focus repeatedly upon Danubian affairs. Unfortunately, both sources need further refinements from a planning perspective. Thus, if Bărbănțan does delve deeper into the historical background of the Danube, Baltălungă writes from a strictly geographical perspective.

It is plain to see that the preceding observations are tentative in nature. As this study is only in its infancy, there is ample room for future refinements. Nonetheless, we do believe that we have finally grasped the correct evolutionary perspective from which to contemplate future research exercises.

\subsection{The Arguments for Linking the Danube to Romania's Development}

The previous section helped survey theoretical strands that have unfolded over the past century within the Romanian literature dedicated to the Danube. We can now proceed to examine the most significant functions of the Danube.

For the sake of convenience, we have grouped these functions into four groups:

1. Law and politics of the Danube;

2. Navigation and trade;

\footnotetext{
1 'The Geography of the Romanian Danube Valley'.
} 
3. River development;

4. Ground water protection and environmental matters.

This classification serves a twofold role: firstly, the four groups act as guidelines for establishing future research agendas, and secondly, they act as benchmarks, in order to ascertain the level of effort that has been put into clarifying these matters.

\subsubsection{Law and Politics of the Danube}

For the purpose of this paper, we are primarily concerned with recent developments in the law and politics of the Danube. Specifically, we shall draw reference to diplomatic efforts after the Second World War. ${ }^{2}$ Given the brevity of this text, we shall work solely with basic principles of foreign policy and their diplomatic expressions. ${ }^{3}$

Specifically, we need answers to the following two questions, in order to draw up a rough sketch of the international role played by the Danube. First, there is the question of the benefits and deprivations, both actual and potential, which might accrue from the control and utilisation of the Danube [46]. And second, there is the matter of defining the exact role the Danube played within foreign policy after the Second World War.

This latter question is important, because the Danube seems to have been a sensitive issue in the exercise of establishing Western and Eastern spheres of influence throughout Europe. Their remnants still tend to complicate international relations today.

\subsubsection{Benefits and Deprivations from Controlling the Danube}

Returning to the first question, we must clearly state from the very beginning that a definitive and comprehensive cost-benefit analysis concerning the control and utilisation of the Danube is almost impossible to undertake, at least for the time being. Such a study would entail an in-depth analysis of international power relations and their dynamics, in order to extract the issues and ideas that are still relevant today. This is impracticable however, as we only have access to a very limited number of comprehensive histories dedicated to the Danube and none of them is up to date. ${ }^{4}$

Nevertheless, we are able to make a few informed comments on this matter:

- Firstly, we contend that the benefits from utilising the Danube are mainly economic in nature;

- Secondly, we have observed that its military function seems to have undergone a steady decline since the Second World War. Current developments in the Ukraine notwithstanding, we find it difficult to

\footnotetext{
${ }^{2}$ There is also a fine strand of Romanian literature dealing with this subject matter [35], [36], [37]. In a future stage of this research project, we aim to undertake a comparative analysis of the dedicated literature, in order to bridge the possible East-West divide.

${ }^{3}$ Hence, we take the notion of 'foreign policy' to denote the sum of decision affecting a country's external relations [46].

${ }^{4}$ Furthermore, these works generally lack a comprehensive perspective of evolutionary economic geography.
} 
believe that the Danube will gain again in military importance any time soon;

- Thirdly, we believe that the Danube still acts as springboard to the Turkish Straits and to the Mediterranean, and hence, is sensitive to current and future geopolitical developments. ${ }^{5}$

The first two points might benefit from an illustration. Thus, the single most serious obstruction of the Danube after the Second World War occurred during the war in Kosovo, in the course of the 1999 North Atlantic Treaty Organization's (NATO) bombings of Yugoslavia. During that period, a total of eight bridges spanning the Danube were partially or completely destroyed. The destruction of the bridges brings us quite directly to the diplomatic importance of the Danube. The river harboured a great deal of both riparian and non-riparian frictions throughout history [16], but the aftermath of the Kosovo War proves highly relevant in relation to international co-operation on the Danube.

Hence, even though the bombings were justified entirely in military terms [58], their consequences were primarily of an economic and environmental nature [59], [60]. Thus, we were unable to find any logical and convincing motivation for the targeted destruction of these bridges during the early days of May 1999 [59]. ${ }^{6} \mathrm{We}$ are therefore inclined to attribute the operations either to poor military planning, or to sheer ignorance on behalf of NATO in matters related to the economic impacts of river navigation. ${ }^{7}$ The first option strikes us as rather unlikely.

Thus, if the bridge bombings were very likely the result of an indifferent military policy, the process of clearing the waterway and restoring its trade function proved to be an unsatisfactory exercise in international policy. Hence, while the economic consequences of the bridge bombings were soon to be capitalised by Germany, through its newly opened Main - Danube canal, which witnessed a spectacular rise in traffic volume, intense negotiations with the Slobodan Milošević's regime were to no avail, as he conditioned the clearance of the river by the reconstruction of the bridges [59]. As a result, the Danube was not fully opened to navigation until 2003.

The four years of blockage resulted in modal shifts and a marked gain in the importance of Adriatic ports. Thus, during early days of the blockage, river traffic was superseded by rail traffic. The question of regulating international rail traffic was solved through an agreement signed between Romania, Hungary, Austria and Germany, which stipulated that each signatory is entitled to use the rail infrastructure of the other countries freely. Nonetheless, this proved to be a mere temporary solution, as rail traffic cost up to $40 \%$ more than waterway transport

\footnotetext{
${ }^{5}$ However, a definitive account of its present geopolitical significance remains to be written.

${ }^{6}$ NATO's main argument was that the bridges were used to reinforce the Yugoslav army. However, there were no important military bases in Northern Vojvodina. Furthermore, the bridges could have easily been disabled, thus preventing traffic across them, but not impeding navigation on the Danube. In addition, the bridges carried water and electricity supply lines, which were severed as a result of the bombings [59].

${ }^{7}$ Surprisingly, the bridge bombing campaign was put to an end by an official request by France, hence saving the bridges of Belgrade. However, navigation on the Danube had already been halted because of the Novi Sad bridge bombings [59].
} 
[59]. Hence, at least part of the modal shift was reversed when the Danube was completely cleared in 2003.

Conversely, the marked gain in the importance of Adriatic ports proved far more difficult to reverse, as they provided an increased frequency of services, as well as a good record of reliability. We therefore believe that at least part of this Adriatic trade will not return to the Danube any time soon.

It is therefore quite clear that the economic benefits arising from controlling the Danube are highly sensitive to political instability. In this respect, the governance of the European Union over much of the Danube acts, at least in principle, as a powerful incentive for a stable river regime. There are, however, other disincentives which prevent the Danube from fulfilling its true economic potential.

Hence, with respect to its current and potential deprivations, the picture is somewhat clearer. We can easily group all the major deprivations under three major headings:

- Obstacles to river navigation and underdeveloped infrastructures. They mainly comprise the fluctuating water regime, which translates in insufficient depths for navigation, ${ }^{8}$ as well as the underdeveloped port infrastructure [59]. ${ }^{9}$ With proper consideration, most of these impediments could be overcome technologically;

- An east to west differential in economic performance and industrialisation [46]. This differential was partly offset by extensive growth policies, pursued during the 1950 s and early 1960 s by the socialist states, but regained momentum during the early 1980s [63];

- Overlapping legal frameworks and often-conflicting international policy. As an illustration of this point, let us remember that Danubian navigation market is currently governed by the application the Danube Commission's regulations, which are only of a recommendatory nature, as well as by the application of specific national navigation regulations, and binding European Union (EU) Directives, which apply only to Member States [71]. On top of all this, there are at least eleven key organisations involved in promoting the development of the Danube, so divergence of opinions is more of the rule rather than the exception [59]. ${ }^{10}$

\footnotetext{
${ }^{8}$ In simpler terms, there are generally 40 to 60 days a year in which the Danube cannot accommodate vessels with a draught of more than 2.0 metres, along three so-called 'pinch zones'. The first such zone is located west of Passau, the second covers almost the entire length of the Hungarian section of the Danube, and the third one incorporates the whole stretch of the Lower Danube, until it reaches the ports of Galați and Brăila. This problem is especially severe for Romania, as it aged fleet generally makes use of the 2.0 metre draught [71].

${ }^{9}$ More specifically, the development of river ports into logistics hubs progresses at quite a slow pace. Romania lags somewhat behind in this respect, as it was primarily concerned with extending the 'free trade zones' to cover entire ports. The most prominent examples are Giurgiu, Galați, Sulina and Constanța [59].

${ }^{10}$ In the year of 2002 , the following agencies were actively promoting the development of the Danube: the Danube Commission (Budapest); United Nations Economic Commission for Europe Inland Transport Committee: Working Party on Inland Water Transport (Geneva); the Transport Infrastructure Needs Assessment: Corridor VII (Vienna); the Southeast European Cooperative Initiative: Danube Transport Working Group (Vienna); the Stability Pact for South Eastern Europe (Brussels); the Danube Cooperation Process (a joint initiative between Austria and Romania); the European Conference of
} 


\subsubsection{The Legacy of the Cold War}

The current institutional architecture governing the Danube is a direct result of the Danubian objectives pursued by American and Soviet foreign policies during the aftermath of the Second World War and the ensuing Cold War. The image is powerful: The United States (US) wished to restore freedom of navigation, on all European inland waterways, based on complete equality between riparian and non-riparian states. ${ }^{11}$ Conversely, the Union of Soviet Socialist Republics (USSR) doggedly pursued the establishment of Soviet political and economic control, reaching from the Black Sea to Bratislava, employing a concept of complete riparian control [46].

With the benefit of hindsight, we can assert that American foreign policy was somewhat naïve in the case of the Danube, as it failed to take into account the sheer tenacity of Soviet foreign policy. Thus, it is now easy to see that Soviet foreign policy during the Cold War changed little from the pre-war years, when it signed the Molotov-Ribbentrop Pact of 1939. At that time, Soviet interests were centred on penetrating the Near East via the Dardanelles and Istanbul. ${ }^{12}$ Gaining control over the mouths of the Danube thus became pivotal in settling both the Eastern ${ }^{13}$ as well as the Central European Questions. ${ }^{14}$ Nothing of importance changed in this stance after the conclusion of the Second World War, as it will become evident from the troubled history of the new Danube Commission.

\section{The Belgrade Conference}

The new Danube Commission was established in the year of $1948,{ }^{15}$ as a result of the Danube River Conference held in Belgrade. By that time, American hope for counterbalancing Soviet control over the Middle and Lower Danube was all but lost, as it was forced to act within the straightjacket of existing institutional arrangements and Soviet good will, in order to reach agreements on all outstanding differences with the USSR [46].

Ministers of Transport (Paris); the 'Via Donau' (Vienna); the Inland Vessel Register (Rotterdam); 'Inland Navigation Europe' (Brussels); and, finally, the European Federation of Inland Ports (Brussels) [59].

${ }^{11}$ Prior to the Second World War, American policy objectives concerned with the Danube simply did not exist. Economic interest was also negligible at best, as most trade on the Danube remained confined to Europe. The end of the Second World War brought a marked change in this state of affairs, with American interests beginning to manifest themselves. Hence, at the Potsdam conference, President Truman suggested freedom of navigation and a broad international regime on all European inland waterways [46].

${ }^{12}$ This is, however, a far older Russian ambition, dating at least from its Czarist period [61].

${ }^{13}$ Consequently, the annexation of Bessarabia in 1940 had far less to do with territorial gains than with the much sought after status of a riparian state [46].

${ }^{14}$ Using an overtly similar logic, the annexation of Bucovina served the purpose of securing the passes through the Eastern Carpathians, in order to gain an exploitable access to the vulnerable Great Hungarian Plain and thence control of the Middle Danube [46].

${ }^{15}$ The 'new' Danube Commission replaced the European Commission of the Danube (Commission Européenne du Danube) as well as the International Danube Commission, both formally established by the Treaty of Paris, in the year of 1856 [13]. 
Against this background, the main objective of the Belgrade Convention was to decide upon the future regime of the Danube. Two mutually exclusive principles motivated the participants: one was the complete internationalisation of the Danube, while the other was an undisputed riparian control over all aspects related to the river.

The conference had five main topics [46]:

1. The principle of freedom of navigation and its implementation;

2. The composition of the new Danube Commission;

3. Its powers;

4. Its relationship to the United Nations;

5. The validity of the 1921 Convention establishing the Statute of the Danube.

The first point was the most contentious. While the American proposal pressed for an absolute freedom of navigation, extended not only over the entire stretch of the Danube, but also over its associated inland waterway system, the socialist riparian states adamantly resisted it. ${ }^{16}$ Hence, port facilities would only be available upon prior agreement with riparian transportation and expeditionary agencies. It is therefore interesting to note that all these facilities were controlled by joint stock companies, established only a few years earlier. ${ }^{17}$ Soviet control over these companies was virtually undisputed, as the general manager and the vicechairmen were Soviet nominees [46].

It is probably worth mentioning that Romania was the first country to form such a joint stock transportation company, ${ }^{18}$ in the summer of 1945 . This special agreement was part of a larger economic agreement, signed earlier that year, through which the Soviet Union pledged herself to offer capital and technical assistance to boost the Romanian economy [47], [48]. Its provisions were straightforward: The Romanian government ceded exclusive rights of use for its entire river fleet, as well as for the use of the ports of Constanța, Brăila, Galați and

${ }^{16}$ Acting as Czechoslovak Foreign Minister, Vladimír Clementis' position is highly illuminating in this respect [51]:

\begin{abstract}
"There is a substantial difference between free navigation and an internationalised river. Internationalisation means equal treatment for riparians and non-riparians and this is a principle we cannot accept. As far as we are concerned, there is no longer any internationalisation of the Danube. There can be no equal treatment for riparians and non-riparians. When we speak of free navigation, we mean navigation under the control of riparians. The internationalised system is a system of the past and we are replacing it with riparian control."
\end{abstract}

\footnotetext{
${ }^{17}$ The history of the joint stock companies can be summarised as follows: After the conclusion of the Second World War, the Soviet Union loosely interpreted the Potsdam Declaration concerning war reparations from Germany, and consequently claimed all assets owned by German nationals or companies during the war as war trophies. A considerable share of the industries within the former German satellites came under this category. Hence, the USSR found herself in possession of numerous industrial assets. As a result, the Soviet government had two options: either to transfer this property to the Soviet Union, or to capitalise upon it locally. Some notable exceptions notwithstanding, it chose the latter, thereby providing the rationale for the joint stock companies [46], [83], [47], [48].

${ }^{18}$ The joint stock company's name was 'Sovromtransport'.
} 
Giurgiu, together with their shipbuilding and repair installations. The official 50\% - $50 \%$ capital subscription to the joint stock company was purely nominal, as there is no evidence of an actual Soviet contribution, except for partially surrendering claims over former German assets and some machinery, which was initially meant for shipment to the USSR as war reparations [46], [83]. It therefore becomes quite clear that genuine freedom of navigation was virtually impossible, due to indirect Soviet control over port installations.

The other four points on the agenda fared just as poorly: The future Commission would be restricted to riparian states only; ${ }_{i}^{19}$ its powers were limited, in the sense that it did not have jurisdiction over Danubian tributaries and canals. The same provision applied to the Chilia and Saint George arms. Riparian countries were thus left in almost complete control of the river. Furthermore, the Maritime Danube and the Iron Gates sector were placed under Special River Administrations, which practically severed all future efforts in internationalising the Danube.

In addition, any connections to the United Nations were deemed unnecessary and possibly damaging. With respect to the 1921 Convention, the assembly declared it void and null. Furthermore, the Belgrade Convention cancelled all obligations for the International Danube Commission and the European Danube Commission to repay credits granted to them.

The conclusion of the Convention marked the end of American involvement in establishing an international regime governing the Danube. At the same time, the Socialist block perceived the resulting protocol as a major diplomatic victory. In spite of that, what emerged from the Convention was a weak Commission having limited powers.

\section{A Concise History of the New Danube Commission}

Roughly speaking, the history of the new Danube Commission after the Belgrade Conference can be divided into three distinct periods [46]:

- A first period of dissension which lasted until the death of Stalin, in 1953;

- A second period of strenuous rapprochement;

- A third period of improved co-operation and a relative openness towards the West, that lasted until the fall of the communist regimes in Eastern Europe.

\footnotetext{
${ }^{19}$ Hence, the members were: Bulgaria, Czechoslovakia, Hungary, Romania, the Ukrainian SSR, the Soviet Union and Yugoslavia.
} 
Specifically, the first period was marred by the Yugoslav-Soviet rift, ${ }^{20}$ which resurfaced repeatedly during the Commission's meetings. Formally, it centred on the Rules of Procedure for electing the Commission's President, Vice President and Secretary. The Yugoslav proposals for rotating all the Commission's posts between the member states, as well as the recruitment of officers on a basis of equality, were consistently rejected by all the other members, Romania included, under the orchestration of the Soviet Union. Upon closer scrutiny, this adamant resistance to Yugoslav proposals translates into a matter of political accountability. Thus, if on the one hand, the President and the Vice President of the Commission exercised only symbolic functions, the Secretariat had virtually unlimited powers. Specifically, the Secretary, or one of his delegates, was mandated to sign all the correspondence with concerned authorities and institutions, whereas the President and Vice President were only authorised to jointly sign, together with the Secretary, the correspondence with governments and international organisations [46].

Furthermore, the Secretary was only accountable to his government and not to the Commission. Hence, when the first Secretary was nominated from the Soviet delegation, the USSR gained an undisputed monopoly over the Commission.

In short, this first period in the Commission's existence was characterised by a thinly veiled disregard for Yugoslav initiatives, as well as by a frustrating information asymmetry between the Soviet-led block and Yugoslavia, which was repeatedly denied access to relevant information concerning the Commission's proceedings.

This period only ended with the Yugoslav walkout from the Commission's meetings. The Soviet response consequently became less adamant, as the USSR could not neglect the importance of Yugoslavia as a riparian state. Moreover, the international context of the Korean War induced a period of relative restraint in Soviet international policy [46].

The situation changed perceptibly after the death of Stalin. Thus, a period of slow rapprochement began in 1953, with the agreement for the joint control and

\footnotetext{
${ }^{20}$ The Yugoslav-Soviet rift was essentially a matter of ideology. The Soviet Union felt that it had the undisputed hegemony over the ideological development of communism. It therefore had a problem with the legitimacy of Tito's regime, which had rallied its supporters based on a patriotic rhetoric, rather than employing a socialist one. Furthermore, the question of Tito's legitimacy had already been settled during the war, thereby making Yugoslavia stand apart from other socialist countries, in which communist rule was achieved through Soviet involvement.
}

The actual rift started well in advance of 1948, when Tito learned of Stalin and Churchill's negotiations on the future architecture of the Western and Eastern spheres of influence, which were to dominate post-war Yugoslavia. Stalin later reciprocated this sense of animosity, when he learned about Tito's plans to form a Balkan federal state, comprising Yugoslavia, Bulgaria and Albania. As a result of these frictions, Soviet-Yugoslav diplomatic relations deteriorated rapidly.

The tension became manifest when Yugoslavia felt that the future Soviet-Yugoslav joint stock companies would be exploitative to her economy. Hence, she duly broke off negotiations with the Soviet Union.

Similarly, the first move on the Soviet side was to suspend all negotiations on the renewal of the general trade agreement, which was pivotal to the formation of joint stock companies. The USSR then recalled all Soviet military advisors and civilian specialists. As a final move, Yugoslavia was expelled from the Information Bureau of the Communist and Workers' Party (Cominform) in the summer of 1948 [65]. 
administration of the Iron Gates sector between Yugoslavia and Romania. Perceived as a sign of Soviet good will, this agreement paved the way for a gradual Yugoslav integration within the Commission, albeit at a relatively large strategic cost for Romania. Thus, at its ninth meeting the Commission agreed to the Yugoslav proposal of moving the Commission's headquarters from Galați to Budapest.

Essentially, this second period witnessed a policy of accommodation with Yugoslavia, prompted by the now visible Graeco-Turkish-Yugoslav alignment, as well as by the Soviet desire to enhance the Commission's reputation as an international body. Concomitantly, it paved the way for closer co-operation.

It was during this third period, that the Commission finally dedicated herself to tackling technical matters related to navigation on the Danube. In addition, the Commission called for the first time for a systematic exchange in information and documentation with other organisations concerned with international water transport. This position indicated a gradual thawing of East - West relations during the mid 1950s, supported by the first-time acceptance of an observer from the Economic Commission for Europe, as well as by the Austrian accession to the Commission in 1958. ${ }^{21}$

Historically, these events unfolded at a time when Romania played a relatively insignificant role in international affairs [62]. Soviet penetration in all aspects of political and economic life was still prevalent [63]. Thus, if political alignment with the Soviet Union was virtually complete by the year 1947, economic restructuring was slower to take hold. Three factors weighed in heavily in this delay: Firstly, there was the physical war damage that followed from the Allied bombings of 1943 and 1944, accompanied by the large loss of human life through military operations. Secondly, there was Romania's imposed refusal to accept the Marshall plan, as a direct result of Soviet pressure, which meant that any restructuring effort would rely heavily on feeble national investment. And thirdly, there was the composition, timing and extent of war reparations bill that had to be paid to the Soviet Union [82].

As a result, economic restructuring only gained momentum in late 1947 and 1948 . It was virtually complete by 1950 , with the notable exception of agriculture, which suffered a process of collectivisation that lasted until 1962. Nonetheless, initial results were far too insubstantial to warrant any strong bargaining position within the Commission. Furthermore, it is only in 1958 that Soviet troops would leave Romanian territory and that a discernible Romanian stance in foreign policy appears, spearheaded by the recovery of the economic, military and intelligence sectors by dismantling the mechanisms of Soviet control [81], [64].

What followed was a period of extensive growth. It would become virtually exhausted by the 1970s [63]. Nonetheless, this period corresponds to a first phase in the complete overhaul in Romanian port infrastructure and fleet improvements

\footnotetext{
${ }^{21}$ Nonetheless, Austria's accession was not hailed as a normalisation of East - West relations by the West, as Austria had already signed bilateral agreements with other riparian states with respect to navigation. Hence, the Austrian initiative can be viewed both as a diplomatic quid pro quo in return to the Soviet decision to substantially reduce her war reparations bill, and as an attempt to seize a larger share of river traffic [46].
} 
[66], which subsequently translated into a more technical approach in dealing with matters of river navigation within the Commission.

Beyond these general observations, it is difficult to accurately pinpoint the exact place the Danube took within Romanian foreign policy during the final decade of the communist regime. The same insight applies for the current period. With no critical synthesis available, we would have to reconstruct the general lines of such a policy from the protocols of the Danube Commission. Regrettably, at the time of writing, we still do not have access to them.

In addition, the relationship between privatisation of Romanian industries and the expression of the country's foreign policy has not been researched in a satisfactory manner to date [67], [68], [69]. It is precisely this relationship that might eventually explain the unfavourable trends in the composition and volume of Romanian trade on the Danube.

\subsubsection{Navigation and Trade}

There is a rich body of literature dedicated to current navigation conditions on the Danube. Interestingly enough, since 2005 it has been published yearly by the Central Commission for the Navigation of the Rhine (CCNR). ${ }^{22}$ However, for the purposes of this paper, we shall concentrate solely upon the 2014 report, which is the latest addition to the series [70].

Let us start with the observation that the Danube is the less favoured waterway within the European inland navigation system. In addition to economic disparities between the Rhine and the Danube regions, this state of affairs is partly explained by the fluctuating water levels, which make the Danube less reliably navigable.

In contrast, its more developed counterpart, the Rhine, accounts for approximately two thirds of the total freight transported on the European inland waterways. It therefore stands to reason that the countries within the Rhine region account for the largest proportion of inland transport volume, with little competition from the countries of the Danube region $[70] .{ }^{23}$

This picture gets even clearer, when one considers the particularities of the three sections, which together compose the Danubian waterway. Thus, the Upper Danube, stretching from Kelheim, in Germany, to Komárno, in Slovakia, exhibits a 3:1 predominance of east-to-west shipments. Specifically, upstream transportation is composed primarily of foodstuffs, fodder, crude oil and iron ore, while downstream transportation consists mainly of fertilisers and crude oil products. This east-to-west imbalance is explained by the steel industry along the Upper Danube, which draws upon raw materials shipped from the Black Sea ports of Constanța and Galați. ${ }^{24}$

\footnotetext{
${ }^{22}$ The reports since 2005 are available at: http://www.ccr-zkr.org/13020800-en.html [30.06.2015].

${ }^{23}$ To illustrate this point, consider, for example, the following figures as a reference framework: in 2013, the Netherlands boasted a total volume of 332 million tonnes of transport volume. It was followed by Germany, with 226.9 million tonnes. Romania accounted for a mere 27 million tonnes, i.e. some $8 \%$ of the total freight volume transported by the Netherlands [70].

${ }^{24}$ A comprehensive analysis of the steel industry of the Upper Danube would greatly exceed the confines of this paper. Nevertheless, this matter is of great interest within this research project. Future papers will therefore include a finer analysis in economic geography.
} 
The Middle Danube, stretching from Komárno to Turnu Severin, is somewhat different, in the sense that the agricultural produce of Hungary and Croatia is partly integrated in global supply chains. The other two Danubian tracts do not share this feature.

And finally, there is the Lower Danube, which is the main focus of our study. This stretch can be further subdivided into riverine section between Turnu Severin and Galați, and the maritime section, between Galați and the Black Sea. What is relevant to our particular study is that transportation on the Lower Danube is heavily dependent on the seaports of Galați and Constanța. Hence, coal and ore movements feature prominently in the share of transport volume. However, both have declined steadily since 2010 . This is in part explained by the Romanian steel industry's lack of comparative advantage [70], which might, in turn, illustrate defective privatisation processes and defensive foreign investments [67], [68]. Further enquiry is needed to clarify these matters.

Nevertheless, we can infer from these observations that the domestic use of the Danube is less important than its international use. Looking at the available datasets, ${ }^{25}$ we can construct a rough ratio of $1: 14$ between national and international transit volumes. ${ }^{26}$ This amounts to very little domestic shipping. Nonetheless, it is interesting to note that Romanian ports on the Danube strike quite a fine balance between imports and exports [72]. ${ }^{27}$ The question remains, however, whether this is a sign of production cycle integration or not.

Again, we are faced with a far-reaching question related to recent Romanian industrial history. Specifically, the patterns linking port infrastructure to production cycles across the country have not been surveyed in recent times. We suspect that there are some missing links, which account for the severely underdeveloped domestic river traffic.

\subsubsection{River Development}

The concept of river development implies that each major river has the potential of fulfilling the following four functions: irrigation, hydroelectric power generation, flood control and navigation. However, the case of the Danube is somewhat special, as it forms a rewarding platform for studying Cold War and post Cold War river development strategies and projects [73].

\footnotetext{
${ }^{25}$ The datasets are included in the publications entitled 'Danube Navigation Statistics', issued by the Danube Commission. At the time of writing, the Commission's webpage only lists the latest additions to the series, namely the issues for 2011-2012, and 2012-2013, respectively. Unfortunately, these two issues alone are insufficient for constructing trend analyses. We therefore intend to purchase the rest of them in the near future.

${ }^{26}$ Expressed in per cent, this ratio amounts to some 7\%. Thus, for the year 2012, which is the most recent year for which data is available, international transit amounted to some 6.3 million tonnes, compared to a mere 0.4 million tonnes of national transit [72].

${ }^{27}$ Unfortunately, finer grained analyses are impossible to undertake at present, as the data seems to be somewhat inconsistent. Nevertheless, we do know that about 2 million tonnes have left Romanian ports on the Danube, headed for foreign ports on the Danube. At the same time, about 2,3 million tonnes have entered Romanian ports on the Danube, with goods loaded in foreign Danubian ports. Finer longitudinal analyses will only be possible when we receive the requested materials from the Danube Commission. At the time of writing, this type of documentation has not reached us yet [28.09.2015].
} 
Thus, starting with the 1950s, the Danube became the theatre of competing development ideologies, under the guise of technical assistance for industrial development. The broader context of these competing efforts was the gradual consolidation of the Western and Soviet spheres of influence along the Iron Curtain. Against this background, technical assistance was ideologically charged, and 'complex' or 'multi-purpose ${ }^{\prime 28}$ river development was the primary instrument used against underdevelopment [73].

\section{Competing River Development Models for the Danube}

Two models were put forward in the case of the Danube. The first one was the Tennessee Valley Authority (TVA) model, which, under Roosevelt's New Deal, had been successfully employed to engender economic development within the Tennessee valley, an area severely hit by the Great Depression and ridden by (energy) market failure [75]. Specifically, the comprehensive river basin development harnessed the power of the Tennessee River for navigation, flood control, hydroelectric power generation, as well as for fertiliser manufacturing. This model proved so successful, that the United States began actively promoting it abroad.

The other model was of Soviet origin, and it embodied the expertise Soviet planners and technicians gained from harnessing the Dnieper River. Supported by the 'State Commission for Electrification of Russia'29 (GOELRO/ГОЭЛPO) and its associated plan for economic recovery and development through electrification, construction of the Dnieprostroi dam was virtually simultaneous with the Hoover dam. Furthermore, the idea behind its construction was similar to that of the TVA model, namely complementing hydropower with irrigation and land improvement, for the benefit of peripheral and lagging regions [73]. There is however a major difference in their international perception. Whereas the TVA model was hailed as a democratic endeavour by its very nature, the Dnieprostroi model was often criticized for its use of forced labour.

Nevertheless, the success of the GOELRO plan prompted the establishment of the Gidroproekt Institute in 1930. The institute would subsequently oversee the design and construction of major infrastructure projects, such as the White Sea - Baltic Canal (1931-1933), the Moscow Canal (1932-1937), the Volga - Don Canal, (1938-1952), as well as continuous improvements of the Volga - Baltic Canal, ${ }^{30}$ especially between 1960 and 1964. In addition, the Gidroproekt Institute planned and executed a host of dams, both across the USSR ${ }^{31}$ and abroad, as well as major irrigation projects. Gidroproekt would consequently become the sole exporter of the Soviet river improvement model.

\footnotetext{
${ }^{28}$ There is no difference in reality between the two terms. 'Complex river development' was common in Soviet use, while 'multi-purpose' or 'comprehensive river development' was used mainly by the Americans [73], [74].

${ }^{29}$ Государственная комиссия по электрификации России. The Commission's plan would become the blueprint for the ensuing Five-Year Plans.

${ }^{30}$ The Volga - Baltic Canal was formerly known as the Mariinsk Canal System (Мариинская водная система).

${ }^{31}$ Especially on the Volga and Kama rivers.
} 
Hence, in 1945 we find both American and Soviet ideas competing for the development of the Danube. Given its character as an international waterway, the river proved to be a fertile ground for disagreements, as each development idea would have to rely heavily on international co-operation.

Essentially, the problem was straightforward: The Danube needed an improved navigational channel, a better management of its tributaries, using multi-purpose dams, and more effective flood controls, especially along the Middle Danube. Furthermore, its potential in generating electricity was seriously underdeveloped. With the benefit of hindsight, we can ascertain that most of the technical solutions were already known by that time. What proved to be a matter of contention was the institutional arrangement geared at solving these issues.

Spearheaded by the US and supported by the United Nations' Economic Commission for Europe (UNECE), the initial development perspective drew upon the TVA model. Consequently, the UNECE established a Danube Study Group within the Electric Power Committee, which was scheduled to have its first meeting in the autumn of 1948. Due to Romania and Bulgaria's refusal to participate, the meeting was eventually cancelled [73]. This is hardly surprising, as the Belgrade Convention had only recently been signed, thereby curtailing all efforts in internationalising the Danube.

Following the Convention, the Soviet Union basically gained control over the whole stretch of the Danube between Austria and the Black Sea. Hence, the preferred modus operandi became the bilateral agreement under the auspices of the Council of Mutual Economic Assistance (CMEA/COMECON), which was established soon after the Convention, in 1949. The CMEA took it upon itself to buttress an increased economic integration between the socialist satellites through sustained technology and knowledge transfers [73], [50]. ${ }^{32}$

\section{The Commission for the Exchange of Electric Energy and Utilisation of the Hydraulic Resources of the Danube River}

Nevertheless, during the Yugoslav-Soviet rift of 1948 and 1953, the CMEA reached virtually no decisions concerning the improvement of the Danube. There was a notable exception, however, which proved to be of a great political significance for Romania: the Danube - Black Sea Canal [52], [53]. Put forward by the Romanian government following Stalin's suggestion, the technical rationale behind its construction was a more direct access to the Black Sea [49]. There was, however, a more strategic twist to the matter: As traffic on the Maritime Danube was still officially governed by the European Danube Commission, now having its seat in Rome, the construction of the Danube - Black Sea Canal would automatically bypass any Western involvement in regulatory matters.

When the Yugoslav-Soviet rift came to an end, the CMEA began assuming a more active role. Hence, in 1956 it established its Commission for the Exchange of Electric Energy and Utilisation of the Hydraulic Resources of the Danube River, a new body that was explicitly put in charge over river improvement. The Commission posited a fundamental principle governing all river improvement

\footnotetext{
32 The political implications of the CMEA are too manifold to explore within this paper. We shall return to this matter in future publications. We would like to note, however, that Romanian sources discussing these matters are scarce and far apart [47].
} 
projects: Projects located in a single country would be pursued unilaterally, while international projects would be pursued bilaterally or multilaterally, as the case might be. In addition, Soviet experts would partake in matters related to planning and co-ordination, but they will refrain from interfering with the execution proper of the projects. Specifically, the Commission established the following plan for the ensuing period of 1956-1958 [73]:

- Firstly, all CMEA member states would collect relevant topographical, geological and hydrological data pertaining to their stretch of the Danube;

- Secondly, the Gidroproekt Institute would conduct a thorough analysis of this data;

- Thirdly, the Commission would prepare a detailed plan for additional research, aimed at narrowing the breadth of viable project sites;

- Fourthly, each member state would decide upon the exact location of its desired projects;

- And lastly, Gidroproekt would make final recommendations with the support of experts from each concerned member state. These recommendations would in turn be discussed and approved by the Commission in 1958.

All went according to plan and in the autumn of 1957, the Commission approved the following master plan: Eleven dams were to be built on the Danube, with a total installed capacity of 5.4 million $\mathrm{kW}$. An additional set of projects, aimed at improving navigation on the Middle Danube, was to complement the dam construction projects. They were accompanied, in turn, by vast land reclamation and irrigation schemes. ${ }^{33}$ The report even listed the possibility of linking the Danube to the Oder and Vistula basins [73].

Little of this ambitious plan eventually came to fruition. Out of the eleven dams, only one was eventually constructed under the auspices of the CMEA, namely the Gabčíkovo dam in Slovakia. It was initially part of the Gabčíkovo-Nagymaros Waterworks, a joint project between Hungary and the former Czechoslovakia. The agreement between the two countries was signed in the autumn of 1977, but Hungary soon pressed for a temporary abandonment of the project, citing economic difficulties. Thus, in 1983, both countries agreed to a slowdown in the implementation of the project. In 1989, the Hungarian government decided to halt all work on the project. In response, Czechoslovakia diverted a significant part of the Danube and started construction of the Gabčíkovo dam in $1991 .{ }^{34}$ In turn, Czechoslovakia's actions led to Hungary's unilateral termination of the agreement, pressed by increasing domestic concerns about environmental impacts of the waterworks. The dispute eventually resulted in a ruling by the International Court of Justice in 1997, which did not succeed, however, in resolving the matter [54], [55].

In contrast, another large river improvement project was actually seen through to completion, albeit not under the aegis of the CMEA. This was the Iron Gates

\footnotetext{
${ }^{33}$ Irrigated lands would then expand by about 5 million hectares [73].

${ }^{34}$ What has become known as Variant ' $C$ ' [54].
} 
project. It moved quite swiftly: Negotiations between Romania and Yugoslavia were finalised by 1956 . Four years later, in 1960, the feasibility study was finished. ${ }^{35}$ Actual construction started very soon after, in 1964, and lasted until 1971. The waterworks went into operation in spring 1972 [56]. Almost a decade later, it was followed by the Iron Gate II project, which opened in 1984.

The Iron Gates project unfolded bilaterally from its inception, thereby circumventing both the Commission and the CMEA. There are two main reasons for this: Firstly, the project was developed at a time when tensions resurfaced between Yugoslavia and the Soviet Union, and secondly, it corresponded to Romania's period as a maverick socialist state.

Hence, the overall implementation of the initial CMEA master plan seems unsatisfactory at best, but the exact reasons are difficult to pinpoint accurately. On the one hand, environmental concerns related to large-scale river improvement projects began to gain momentum during the 1970s and 1980s. The GabčíkovoNagymaros Waterworks is a case in point. On the other hand, hydropower witnessed an increased competition from nuclear power, thereby losing at least part of its importance. There is probably an additional reason: the lack of direct Soviet involvement in the construction of the river improvement projects. Hence, it is curious that the Gidroproekt Institute refrained systematically from directing construction works, leaving the implementation solely with the riparian states. It would be therefore interesting to fathom why the Soviet Union did not play a more overt role in fulfilling the initial CMEA master plan. This is probably a question of foreign policy, which has remained undocumented to date.

Hence, as the previous account shows, completed projects are few and far apart, thus leaving the Danube's theoretical potential for river development largely unfulfilled. It also seems highly improbable that the Danube will witness any new major river improvement projects, given the public's concern about the impact of such large-scale projects.

Nevertheless, there is an additional point we wish to stress here: Even if the Iron Gates II Waterworks was the last completed major river improvement project on the Danube, Romania continued to contemplate domestic river improvement programmes until the fall of the communist regime. Notable examples include the Bucharest - Danube Canal and the Siret - Bărăgan river improvement scheme. Unfortunately, both projects received little academic coverage. Therefore, the only available sources of information are the unpublished projects themselves. A future research effort will need to unearth these valuable documents, which probably still lie in the archives of the former Institute for Hydrotechnical and Transportation Planning (IPHD), ${ }^{36}$ now called the Institute for Transportation Planning (IPTANA). ${ }^{37}$

Furthermore, we have become aware of the fact that the brief history of river improvement on the Danube does point to a completely novel field of enquiry, namely the electrification of Eastern Europe as a hallmark of economic integration. There are a few good histories of the electrification of Western Europe [57], but

\footnotetext{
${ }^{35}$ It had been prepared jointly by the Romanian Institute for Hydrotenergetic Research and Planning (Institutul de Studii și Proiectări Hidroenergetice/ISPH) and the Yugoslav Energoprojekt [56].

${ }^{36}$ Institutul de Proiectări Hidrotehnice și Drumuri/IPHD.

${ }^{37}$ Institutul de Proiectări pentru Transporturi Auto, Navale și Aeriene/IPTANA.
} 
there is virtually no comprehensive literature on the electrification of Eastern Europe.

\subsubsection{Groundwater Protection and Environmental Matters}

Compared to trans-boundary freshwater regulation, international groundwater regulation is a relatively new concern [76]. Within the European Union (EU), the EU Water Framework Directive (WFD) ${ }^{38}$ is the primary document governing groundwater quality. It has been adopted by the European Parliament and the Council of the European Union in a co-decision procedure. As a European Directive, it is legally binding to each Member State.

The Directive is also highly ambitious: All Member States have to achieve a good quantitative and qualitative, i.e. chemical, groundwater status by December this year (2015). In simple terms, they have to balance abstraction and recharge of groundwater, while concomitantly protecting the aquifers ${ }^{39}$ and enhancing them [77].

The more challenging part is the protection of aquifers, as it bears upon groundwater pollution. Hence, six years after the WFD, an additional Directive, called the Groundwater Directive, began regulating this field..$^{40}$ It sets groundwater quality standards and introduces measures to prevent groundwater pollution.

Both Directives are based on river basin districts as primary management units. ${ }^{41}$ From a geographical perspective, there is a single trans-boundary groundwater body (GWB) ${ }^{42}$ located on the Danube itself, which is shared jointly between

\footnotetext{
${ }^{38}$ The exact title of the EU Water Framework Directive is 'Directive 2000/60/EC of the European Parliament and of the Council establishing a framework for the Community action in the field of water policy'. It was published in Official Journal of the European Union on 22.12.2000 (OJ L 327). Its consolidated version is available at:
}

http://eur-lex.europa.eu/legal-content/EN/TXT/PDF/?uri=CELEX:02000L0060-20140101\&from=EN [28.06.2015].

${ }^{39}$ A definition is here due. In Article 2 ('Definitions'), §§ 11 and 12, the WFD defines an aquifer as a "[...] subsurface layer or layers of rock or other geological strata of sufficient porosity and permeability to allow either a significant flow of groundwater or the abstraction of significant quantities of groundwater", while a body of groundwater is "a distinct volume of groundwater within an aquifer or aquifers".

${ }^{40}$ Its complete title is 'Directive 2006/118/EC of the European Parliament and of the Council on the Protection of Groundwater against Pollution and Deterioration'. It was published on the 12.12.2006 in the Official Journal of the European Union (OJ L 372). It is available at:

http://eur-lex.europa.eu/legal-content/EN/TXT/PDF/?uri=CELEX:32006L0118\&from=EN [28.06.2015].

${ }^{41}$ The WFD defines a river basin (Article 2 ('Definitions'), $\S \S 13$ and 15) as "the area of land from which all surface run-off flows through a sequence of streams, rivers and, possibly, lakes into the sea at a single river mouth, estuary or delta". A river basin district "means the area of land and sea, made up of one or more neighbouring river basins together with their associated groundwater and coastal waters, which is identified under Article 3(1) as the main unit for management of river basins."

${ }^{42}$ Additional information appears in the 'Atlas of Transboundary Aquifers', published by the United Nations Educational, Scientific and Cultural Organisation (UNESCO) in 2009, through its International Shared Aquifer Resources Management (ISARM) initiative. The atlas is freely available at: http://www.isarm.org/publications/324 [11.10.2015]. 
Romania and Bulgaria. ${ }^{43}$ Unfortunately, its exact state is impossible to accurately assess at present. Analyses are sparse yet, but they point to a less than satisfactory state of affairs [78]. However, domestic technical solutions to aquifer pollution are available and have already been tested locally [79].

A look at the quality of surface waters reveals a similar picture: There are few domestic rivers which display a 'good status' on the maps produced by the International Commission for the Protection of the Danube River (ICPDR). ${ }^{44}$ The Danube makes here no exception: it is listed as 'failing good status'. Furthermore, nutrient pollution, both as nitrogen compounds and phosphates, features prominently in almost all regions crossed by rivers draining the Danube basin. In addition, some local underground water bodies, such as the Buzău - Ialomița aquifer, also exhibit high levels of pollution by chlorine compounds and lead [80].

The connection between poor aquifer quality and spatial planning is poignant: The two major causes for aquifer pollution are fertiliser runoff and infiltration, and the lack of wastewater treatment plants in rural settlements [80].

Hence, aquifer pollution, as well as surface water pollution, seems to be primarily a domestic problem, at least for the time being. It is therefore highly unlikely that Romania is able to play a leading role in mitigating environmental issues within the entire Danube river basin. Nonetheless, there is ample room for efficient environmental planning on a national scale.

\section{CONCLUSIONS AND OPEN QUESTIONS}

A careful examination of the four major functions of the Danube reveals a complicated institutional and political architecture governing the river. At present, Romania seems ill prepared to capitalise upon it. Therefore, from an international perspective, Romania's actual relation to the Danube is ambiguous. Political statements notwithstanding, recent progress in developing these functions seems meagre at best. The same observation applies to domestic relations to the Danube. Unfortunately, this most unsatisfactory state of affairs is closely mirrored within the academic field, where there is little interest in a renewed study of the river and its importance for spatial development. The need for renewed academic enquiries is even more pressing now, as the bordering Danubian regions face some of the worst demographic and economic prognoses within the country.

\subsubsection{Conclusions}

At the end of this exercise, we have arrived at the following three conclusions:

1. The Danube seems to be one of the most rewarding avenues of studying European discrepancies on a large scale. As such, we think it is an excellent illustration of Romanian spatial development paths in a wider Balkan and European context;

\footnotetext{
${ }^{43}$ It is called the 'Upper Jurassic - Lower Cretaceous' and has an area of $24,461 \mathrm{~km}^{2}$, out of which $11,427 \mathrm{~km}^{2}$ (ca. $47 \%$ ) are on Romanian soil. It is located roughly between the Vedea River and the Danube - Black Sea Canal.

${ }^{44}$ The maps are available at the following address: http://www.icpdr.org/main/publications/mapsdanube-river-basin-district-management-plan-2009 [30.09.2015].
} 
2. Furthermore, we have also uncovered some geopolitical points of interest, which hint towards some unresolved issues within the region. They might partially explain the spatial development inertia pervading the entire region. Thus, even after the Kosovo war, the Danube, and especially its lower tract, seems to have remained an inefficient waterway, with detrimental economic consequences for riparian countries. Set against this background, effective international co-ordination is still difficult to document;

3. The two points mentioned above amount to a lack of integration within the Danube region. Historical hindrances to integration are sufficiently well documented. What is missing is a more technical history of the Danube, linking river improvement projects to the century old efforts in electrifying Europe. This connection is no mere fancy, as the construction of the European electricity network proves to be the most fitting method of studying the technical prerequisites to economic integration, as Langendijk has proved admirably.

Clearly, these conclusions are drawn in very broad strokes. On the one hand, they are consistent with the character of the paper, yet on the other, there is something more to it: most of the novel research directions we have uncovered need extensive preparatory work that simply does not exist today. It is therefore essential to establish future research agendas.

\subsubsection{Open Questions}

Hence, we have constructed a series of open questions, conceived as a reference framework for the ensuing stages of this research project:

1. The overarching question is whether past and current demographic developments and economic performance dynamics, both domestically and internationally, are conducive to any sort of meaningful spatial planning endeavour on the Lower Danube;

2. In addition, we would like to place the Lower Danube in a wider economic perspective, in order to discern possible historical business cycles. They might eventually prove beneficial in detecting unsustainable divergence patterns, arising from steadily increasing disparities;

3. And finally, we need to undertake an in-depth analysis of possible endogenous catalysts available in the region, as there is little hope of an increased exogenous influence of the Danube.

In the end, this three-tiered system of open questions will serve the purpose of determining an approximate level of regional resilience along the Lower Danube. This question of resilience might hopefully reorient domestic and international academic interest towards the Danube. 


\section{References}

[1] European Commission (EC) (2010a), Communication from the Commission to the European Parliament, the Council, the European Economic and Social Committee and the Committee of the Regions. European Union Strategy for the Danube Region. $\{\operatorname{SEC}(2010) 1489\},\{\operatorname{SEC}(2010) 1490\},\{\operatorname{SEC}(2010) 1491\}$ Available at: http://www.danube-region.eu/component/edocman/communicationof-the-commission-eusdr-pdf [04.06.2015].

[2] EC (2010b), Commission Staff Working Document. Action Plan. Accompanying Document to the Commission to the European Parliament, the Council, the European Economic and Social Committee and the Committee of the Regions. European Union Strategy for the Danube Region $\{\operatorname{COM}(2010) 715\}$. Avaliable at: http://www.danube-region.eu/component/edocman/action-plan-eusdr-pdf [04.06.2015].

[3] Rudescu, L. and Banu, A. C. (1969), Bibliographie roumaine du Danube Inferieur, Commission Nationale de la Republique Socialiste de la Roumanie pour I'UNESCO, Bucharest.

[4] Popescu, T., Adam, S., Abăluță, C., Rusan, R., Motoc, N., Moraru, C., Genaru, O., Iorgulescu, M., Mareș, R., Brumaru, A. I., Chirilă, D., Dimisianu, G. and Culcer, D. (2001), "Tezele din iulie" ["The July Theses"], Revista Literară Vatra, 8, pp. 3166.

[5] Stoica, S. (2012), Istoriografia românească între imperativele ideologice și rigorile profesionale [Romanian Historiography between Ideological Imperatives and Professional Rigours], Editura Meronia, Bucharest.

[6] Antipa, G. (1907), Punerea în valoare a terenurilor de inundațiunea a Dunărei [Capitalising upon the Danubian Floodplains], Stabiliment de Arte Grafice Albert Baer, Bucharest.

[7] Antipa, G. (1910/1912), Das Überschwemmungsgebiet der unteren Donau. Sein heutiger Zustand und die Mittel seiner Verwertung. Separatdruck aus dem „Anuarul Institutului Geologic al României”, IV. Band, 1910, 2. Heft, Graphisches Institut Carol Göbl, Nachf. I. St. Rasidescu, Bucharest.

[8] Antipa, G. (1913), Trei memorii privitoare la ameliorarea regiunei inundabile a Dunărei, prezentate D-lui Ministru al Agriculturei și Domeniilor de Dr. Gr. Antipa [Three Reports Concerning Land Reclamation in the Danubian Floodplains, Presented to His Excellency, the Minister for Agriculture and the Estates, by Dr. Gr. Antipa], Imprimeriile Independența, Bucharest.

[9] Antipa, G. (1912), Cercetările hidrobiologice în România și importanța lor științifică și economică [Romanian Hydrobiological Research and Its Scientific and Economic Importance], Librăriile Socec \& Comp., C. Sfetea și Librăria Națională, Bucharest.

[10] Antipa, G. (1913), Fischerei und Flussregulierung, Tipografia del Senato, Roma.

[11] Băcoianu, C. I. (1913), Handelspolitische Bestrebungen zur Erschließung der unteren Donau. Die wirtschaftliche Bedeutung des Schwarzen Meerhafens von Constantza einst und jetzt. Ein Beitrag zur rumänischen Eisenbahn- und 
Wasserstraßenpolitik, J. Schweitzer Verlag (Arthur Sellier), Munich, Berlin and Leipzig.

[12] Băcoianu, C. I. (1914), Patria maritimă și fluvială românească. Podul transdunărean româno-bulgar. Problema Dardanelelor în lumina interesului românesc. O problemă de strategie comercială [The Romanian Maritime and Riverine Homeland. The Danubian Bridge between Romania and Bulgaria. The Question of the Hellespont (Dardanelles) in the Light of Romanian Interests. A Matter of Commercial Strategy], Institutul de Arte Grafice ,Eminescu', Bucharest..

[13] Băicoianu, C. I. (1915/1917), Le Danube. Aperçu historique, économique et politique, Librairie de la Société du Recueil Sirey, Paris.

[14] Vidrașcu, I. G. (1911), Istoricul îndiguirilor fluviale și maritime [A History of River and Coastal Defences], Tipografia Curții Regale F. Göbl Fii, Bucharest.

[15] Vidrașcu, I. G. (1921), Valorificarea regiunei inundabile a Dunărei [The Capitalisation of the Danubian Floodplain], Tipografia ,Urbana', Bucharest.

[16] Iorga, N. (1913/1998), Chestiunea Dunării. Istorie a Europei Răsăritene în legătură cu această chestie [The Question of the Danube. An Eastern European History in Relation with this Affair], Institutul European, Iași.

[17] Ministerul Agriculturii și al Domeniilor [The Ministry of Agriculture and the Estates] (1929), Îndiguirile regiunei inundabile a Dunărei. Desbaterile Comisiunei Îndiguirilor, Ianuarie - Aprilie 1929 [The River Defences of the Danubian Floodplain. Proceedings of the River Defence Committee, January - April 1929], Tip[ografiile] Române Unite, Bucharest.

[18] Lazarovici, E. B. (1920), "Construcția și exploatarea portului Constanța” ["Construction and Operation of the Port of Constanța"], Analele Dobrogei, 1, 1, pp. 39-100.

[19] Zambaccian, K. H. (1920), „Portul Constanța și România Mare" ["The Port of Constanța and Greater Romania"], Analele Dobrogei, 1, 2, pp. 310-313.

[20] Stoenescu-Dunăre, I. (1922), "Canalul navigabil Cernavodă - Constanța" ["The Cernavodă - Constanța Canal"], Analele Dobrogei, 3, 3, pp. 388-410.

[21] Delamare, B. (1922), "Bosforul, Dardanelele și țara noastră" ["The Turkish Straits and Our Country"], Analele Dobrogei, 3, 3, pp. 423-434.

[22] Cotovu, V. B. (1923), "Vederi asupra portului Constanța" ["A Study on the Port of Constanța"], Analele Dobrogei, 4, 1, pp. 50-62.

[23] Zambaccian, K. H. (1923), „Activitatea portului Constanța” ["Trade and Operations in the Port of Constanța"], Analele Dobrogei, 4, 1, pp. 81-86.

[24] Cotov, V. (1923), "Un proect unguresc pentru Cernavodă - Constanța" ["A Hungarian Project for the Cernavodă - Constanța Canal"], Analele Dobrogei, 4, 3, pp. 312-315.

[25] Stoenescu-Dunăre, J. (1927), "Canalul navigabil dela Cernavodă la Constanța" ["The Cernavodă - Constanța Canal"], Analele Dobrogei, 8, pp. 149161.

[26] Stoenescu-Dunăre, J. (1930), "Canalul navigabil dela Dunăre la Mare (Cernavodă - Constanța) și perspectiva unei Baze Navale la lacul Tașaul" ["The 
Cernavodă - Constanța Canal and the Proposal of a Naval Base on Lake Tașaul"], Analele Dobrogei, 11, pp. 175-180.

[27] Dascovici, N. (1938), "Le problème du Danube", Affaires Danubiennes, 1, 1 , pp. 57-61.

[28] Steriopol, N. (1940), "La marine marchande du Danube en 1940", Affaires Danubiennes, 1, 7, pp. 45-55.

[29] Dascovici, N. (1940), "La neutralité de la Roumanie et du Danube", Affaires Danubiennes, 1, 7, pp. 57-60.

[30] Bakidzis, E. (1940), "Les pays du Bas-Danube. Etude géopolitque”, Affaires Danubiennes, 1, 7, pp. 61-84.

[31] Hantos, E. (1941), "L'Europe Danubienne d'hier et d'aujourd'hui", Affaires Danubiennes, 4, 1-2, pp. 5-11.

[32] Steriopol, N. (1941), "Une nécessité: La coopération des marines marchandes Roumaine et Allemande sur le Danube", Affaires Danubiennes, 4, 3-4, pp. 137-139.

[33] Vulcan, C. (1942), "Le statut du Danube pendant la guerre actuelle", Affaires Danubiennes, 5, 1-2, pp. 47-55.

[34] Gogeanu, P. (1966), Strîmtorile Mării Negre de-a lungul istoriei [The Turkish Straits Throughout History], Editura Politică, Bucharest.

[35] Cârțână, I. and Seftiuc, I. (1972), Dunărea în istoria poporului român [The Danube within the History of the Romanian People], Editura Științifică, Bucharest.

[36] Cârțână, I. and Seftiuc, I. (1974), România și problema strîmtorilor [Romania and the Question of the Turkinsh Straits], Editura Științifică, Bucharest.

[37] Florescu, G. G. (1975), Navigația în Marea Neagră, prin strîmtori și pe Dunăre. Contribuții la studiul dreptului riveranilor [Navigation on the Black Sea, On the [Turkish] Straits, and On the Danube. Contributions to the Study of Riparian Law], Editura Academiei Republicii Socialiste România, Bucharest.

[38] Popp, N. (1985), Fluviul Dunărea [The Danube River], Editura Științifică și Enciclopedică, Bucharest.

[39] Popp, N. (1988), Bazinul Dunării. Natură și om [The Danube River Basin. Nature and Man], Editura Litera, Bucharest.

[40] Niculescu, G. (ed.) (1969), Geografia văii Dunării românești [The Geography of the Romanian Danube Valley], Editura Academiei Republicii Socialiste România, Bucharest.

[41] Cucu, V. (1970), Orașele României [The Cities of Romania], Editura Științifică, Bucharest.

[42] Bărbănțan, G. (2009), „Aspecte privind dezvoltarea navigației dunărene în spațiul românesc (1829-1878)" ["Aspects Regarding the Development of Navigation on the Danube within the Romanian Territory (1829-1878)"], Banatica, 19, pp. 187-202. Available at: http://banatica.ro/media/b19/gbap.pdf [26.09.2015]. 
[43] Bărbănțan, G. (2009), „Problema navigabilității în regiunea Porților de Fier în timpurile moderne și implicațiile sale politice și economice" ["Navigation on the Iron Gates Sector During Modern Times and Its Economic and Political Consequences"], Society and Politics, 3, 2, pp. 105-117.

[44] Bărbănțan, G. (2011), Din istoria navigației și comerțului dunărean (de la Vârciorova la Calafat) [The History of Danubian Navigation and Trade (From Vârciorova to Calafat)], Argonaut, Cluj.

[45] Baltălungă, A. A. (2008), România. Orașele porturi dunărene: Geografie umană și economică, Editura Cetatea de Scaun, Târgoviște.

[46] Gorove, S. (1964), Law and Politics of the Danube, Martinus Nijhoff, The Hague.

[47] Țăranu, L. (2007), România în Consiliul de Ajutor Economic Reciproc, 1949-1965 [Romania within the Council for Mutual Economic Assistance, 19491965], Editura Enciclopedică, Bucharest.

[48] Stanciu, C. (2009), Frăția socialistă. Politica RPR față de țările lăgărului socialist, 1948-1964 [The Socialist Comradeship. Romanian Policy towards the Socialist Countries, 1948-1964], Editura Cetatea de Scaun, Târgoviște.

[49] Sonea, G. (2007), Știința și tehnologia autohtone în dezvoltarea României, 1938 - 1989, Editura Agir, Bucharest.

[50] Wallace, W. V. and Clarke, R. A. (1986), Comecon, Trade and the West, Frances Pinter Publishers, London.

[51] United States Department of State (1948), Documents and State Papers, Vol. 1, No. 2. Available at: http://hdl.handle.net/2027/uc1.b3266700 [24.09.2015].

[52] Stănescu, M. (2012), Reeducarea în România comunistă (1945-1955). Volumul III: Târgu-Ocna, Ocnele Mari, Canalul Dunăre - Marea Neagră [Reeducation in Communist Romania (1945-1955). Volume III: Târgu-Ocna, Ocnele Mari, [and] the Danube - Black Sea Canal], Polirom, Iași.

[53] Hossu-Longin, V. (2013), Canalul Morții. Martor [The Death Canal. Witness], Editura Fundației Academia Civică, Bucharest.

[54] Fürst, H. (2006), "The Hungarian-Slovakian Conflict over the GabčíkovoNagymaros Dams: An Analysis", Intermarium, 6, 2, pp. 1-15.

[55] Lipschutz, R. D. (1997), "Damming Troubled Waters: Conflict over the Danube, 1950-2000", Intermarium, 2, 1, no pages given.

[56] Voinea, R. P. (2003), 30 de ani de la inagurarea sistemului hidroenergetic și de navigație Porțile de Fier I (1972-2002) [30 Years since the Inauguration of the Iron Gates I Waterworks (1972-2002)], Alma, Craiova.

[57] Langendijk, V. (2008), Electrifying Europe. The Power of Europe in the Construction of Electricity Networks, Amsterdam Univerity Press, Amsterdam.

[58] Chomsky, N. (1999), The New Military Humanism. Lessons from Kosovo, Common Courage Press, Monroe (ME).

[59] Martin, E. (2002), "International Waterway in Crisis: The Case of the Danube River", IAME Panama 2002 Conference Proceedings. 
[60] Stephan, U., Strobel, U., Weller, P., Bachmann, J. and Klaß, R. (1999), "Kosovo-Konflikt: Ökologische Auswirkungen, Umweltwissenschaften und Schadstoff-Forschung", 11, 6, pp. 313-320.

[61] Ionescu, M. E. (ed.) (2006), Marea Neagră, de la ,lacul bizantin', la provocările secolului XXI [The Black Sea, from a 'Byzantine Lake' to the Challenges of the 21st Century], Editura Militară, Bucharest.

[62] Zaharia, D. (2014), Politica externă a României de la izolare la începerea negocierilor de aderare la Uniunea Europeană [Romania's Foreign Policy between [Romania's] Isolation and the Negotiations Preparing [Her] Accession to the European Union], Editura Cetatea de Scaun, Târgoviște.

[63] Eichengreen, B. (2007), The European Economy since 1945. Coordinated Capitalism and Beyond, Princeton University Press, Princeton (NJ).

[64] Watts, L. L. (2010), With Friends Like These... The Soviet Bloc's Clandestine War Against Romania, Editura Militară, Bucharest.

[65] Brown, A. (2009/2010), The Rise and Fall of Communism, Vintage Books, London.

[66] Iordănescu, D. and Georgescu, C. (1986), Construcții pentru transporturi în România. Monografie. Volumul II [Transport Infrastructure Constructions in Romania. Monograph. $2^{\text {nd }}$ Volume], Centrala de Construcții Căi Ferate (CCCF), Bucharest.

[67] Pasti, V. (1995), România în tranziție: Căderea în viitor [Romania in Transition: The Fall into the Future], Nemira, Bucharest.

[68] Pasti, V. (2006), Noul capitalism românesc [The New Romanian Capitalism], Polirom, Iași.

[69] Gros, D. and Steinherr, A. (2004), Economic Transition in Central and Eastern Europe. Planting the Seeds, Cambridge University Press, Cambridge (CAM).

[70] Central Commission for the Navigation on the Rhine (CCNR), the European Commission (EC) and Panteia (2014), Inland Navigation in Europe. Market Observation 2014. Avaliable at: http://www.ccrzkr.org/files/documents/om/om14_en.pdf [30.06.2015].

[71] Central Commission for the Navigation on the Rhine (CCNR) and the European Commission (EC) (2012), Inland Navigation in Europe. Market Observation $2012 \quad-\quad 1 . \quad$ Available at: http://www.ccrzkr.org/files/documents/om/om12I_en.pdf [30.06.2015].

[72] Danube Commission (2013/2014?), Danube Navigation Statistics for 20122013. Available at:

http://www.danubecommission.org/uploads/doc/STATISTIC/Statistics\%2020122013\%20Rev\%201\%20EN.pdf [06.10.2015].

[73] Langendijk, V. (2014), "Divided Development: Post-War Ideas on River Utilisation and Their Influence on the Development of the Danube", The International History Review, pp. 1-19. 
[74] Miller, B. A. and Reidinger, R. B. (eds.) (1998), "Comprehensive River Basin Development. The Tennessee Valley Authority. World Bank Technical Paper No. 416", The World Bank, Washington DC.

[75] Hiltzik, M. (2011), The New Deal. A Modern History, The Free Press, New York (NY).

[76] Eckstein, Y. and Eckstein, G. E. (2005), "Transboundary Aquifers: Conceptual Models for Development of International Law", Ground Water, 43, 5, pp. 679-690.

[77] Reichert, G. (2011), "Transboundary Gorundwater Law in Europe: A Look at an Evolving Multi-Level Regime", Water International, 36, 5, pp. 686-691.

[78] Barac, M., Maria, D., Arghirescu, A. and Antoniac, C. (2011), "Acviferul Dobrogei de Sud sub influența Canalului Dunăre - Marea Neagră și a factorilor antropici, potențial poluatori ai acestuia" [The Southern Dubrudjan Aquifer under the Influence of the Danube - Black Sea Canal and Potentially Polluting Anthropic Factors], Ecoterra, 26, pp. 1-6.

[79] Bica, I., Alboiu, I. N., Iancu, I., Dimache, A., Ștefănescu, M., Voicu, A., Lăzăroaie, M., Cîrstea, D., Onuțu, I. and Petrișor, I. G. (2009), "Innovative Forensic Assessment and Remediation Strategies for Polluted Aquifers", Environmental Forensics, 10, 3, pp. 214-228.

[80] Administrația Națională "Apele Române" [The National Water Administration] (2015), Sinteza calității apelor din România în anul 2014 (extras) [Water Quality in Romania (Excerpts)]. Available at: http://www.rowater.ro/Lists/Sinteza\%20de\%20calitate\%20a\%20apelor/Attachmen ts/14/Sinteza\%20calitatii\%20apelor\%20din\%20Romania\%20in\%20anul\%202014_ EXTRAS_final.pdf [30.09.2015].

[81] Croitor, M. (2012), "Gheorghiu-Dej și "Declarația de independență" din 1964. PMR între Moscova și Beijing" ["Gheorghiu-Dej and the 'Declaration of Independence' of 1964. The Romanian Workers' Party between Moscow and Beijing"], Bosomitu, Ș. And Burcea, M. (eds.), Spectrele lui Dej. Incursiuni în biografia unui dictator [Spectres of Dej. Incursions in the Biography of a Dictator], Polirom, Iași, pp. 298-318.

[82] Murgescu, B. (2010), România și Europa. Acumularea decalajelor economice (1500-2010) [Romania and Europe. The Accretion of Economic Disparities (1500-2010)], Polirom, Iași.

[83] Constantinescu, N. N. (ed.) (2000), Istoria economică a României. Volumul 2. 1939-1989 [An Economic History of Romania. $2^{\text {nd }}$ Volume. 1939-1989], Editura Economică, Bucharest.

Article distributed under a Creative Commons AttributionNonCommercial-NoDerivatives 4.0 International License (CC BY-NC-ND). Received October 14, 2015 Accepted October 30, 2015 